\title{
Pemberdayaan Masyarakat Dalam Perspektif Collaborative Governance (Studi Kasus Kelompok Budidaya Ikan Mina Bayu Lestari dan Dinas Kelautan dan Periakanan Kabupaten kulon Progo)
}

\section{${ }^{1}$ Nopriono ${ }^{2}$ Suswanta}

${ }^{1}$ Ilmu Pemerintahan, Fakultas Ilmu Sosial dan Politik, Universitas Muhammadiyah Yogyakrta

${ }^{2}$ Ilmu Pemerintahan, Fakultas Ilmu Sosial dan Politik, Universitas Muhammadiyah Yogyakrta

1№priono97@gmail.com;

22soes.umy@yahoo.com

\section{Artikel Info:}

Diterima : 01 November 2019

Direvisi : 10 November 2019

Disetujui : 30 Desember 2019

\section{ABSTRAK}

Kabupaten Kulon Progo adalah salah satu kandidat kabupaten dengan angka kemiskinan yang cukup tinggi jika dibandingkan dengan kabupaten-kabupaten lain di DIY dengan tingkat kemiskinan mencapai 20 persen. Salah satu inovasi yang dilakukan oleh pemerintah dalam menekan angka kesejahtraan dan kemiskinan di Kulon Progo adalah dengan bentuk kolaborasi dalam pembudidayaan ikan. Sehingga hal itu yang melatar belakangi penulis untuk meneliti bentuk collaborative governance yang terjadi dalam kegiatan pembudidayaan ikan gurame dengan konsep pemberdayaan masyarakat.Penelitian ini menggunakan metode penelitian kualitatif dengan proses pengumpulan data peneliti melalui proses wawancara, observasi dan dokumentasi yang dilakukan kepada Dinas Kelautan dan Perikanan Kabupaten Kulon Progo, Kelompok Budidaya Ikan Mina Bayu Lestari dan Pemerintah Desa Hargomulyo. Berdasarkan hasil penelitian yang dilakukan menunjukan bahwa bentuk collaborative governance yang dilkukan sudah berjalan secara baik, hal ini diukur dari beberapa indikator seperti starting condition, fasilitative leadership, design istitusional dan collaborative process yang sudah berjalan sesuai dengan semestinya. Sehingga hal ini mempengaruhi hasil sementara proses kolaborasi yang menunjukan bahwa pelaksanaan kolaborasi selain dapat meningkatkan produktifitas ikan hasil budidaya di Kabupaten Kulon Progo, sehingga dengan adanya bentuk kolaborasi ini juga diharapkan akan meningkatkan jumlah pendapatan masyarakat dan pengentasan kemiskinan serta pengangguran terutama di Desa Hargomulyo.

Kata Kunci: Collaborative governance, Pemberdayaan masyarakat, Stakeholder

\section{ABSTRACT}

Kulon Progo Regency is one of the district candidates with a relatively high poverty rate when compared to other districts in DIY with a poverty rate reaching 20 percent. One of the innovations carried out by the government in suppressing welfare and poverty rates in Kulon Progo is a form of collaboration in fish cultivation. So that is the background of the writer to examine the form of collaborative governance that occurs in the cultivation of carp with the concept of community empowerment. This research uses qualitative research methods with the process of collecting researcher data through interviews, observations and documentation conducted to the Department of Marine and Fisheries District Kulon Progo, Mina Bayu Lestari Fish Farming Group and Hargomulyo Village Government. Based on the results of research conducted shows that the form of collaborative governance that has been done is going well, this is measured by several indicators such as starting conditions, facilitative leadership, institutional design and collaborative processes that have been running accordingly. So that this affects the interim results of the collaboration process which shows that the implementation of collaboration in addition to increasing the productivity of fish farming in Kulon Progo Regency, so that with this form of collaboration it is also expected to increase the amount of community income and alleviate poverty and unemployment especially in Hargomulyo Village.

Keywords: Collaborative governance, Community Empowerment, Stakeholders 


\section{PENDAHULUAN}

Pemerintahan merupakan salah satu unsur terpenting dalam terciptanya sebuah negara, pemerintah dibutuhkan dalam segala bentuk kegiatan yang berkaitan dengan politik, ekonomi, pembangunan, sosial, hukum maupun segala bentuk kegiatan yang menyangkut hajat hidup orang banyak yang berada dalam lingkup pemerintahan pusat, pemerintahan daerah atau bahkan Desa. Dalam prinsipnya konsep pemerintahan yang baik atau Good Governance tidak akan pernah lepas dengan 3 sektor utama yaitu antara lain state (Negara atau Pemerintah), Society (masyarakat) and Private Sektor (sektor swasta atau dunia usaha) yang saling berinteraksi menjalankan fungsinya masing-masing secara beriringan. (sedarmayanti, 2012)

Dalam menjalankan roda pemerintahan, terutama dalam menjalankan tugas pokok dan fungsinya sesuai dengan visi dan misi yang ingin dijalankan, tak jarang pemerintah sering kali berjalan secara berdampingan dengan cara berkolaborasi atau bekerjasama dengan kelompok kepentingan lain untuk mencapai target pelaksanaan program pemerintahan yang igin dicapai. Kolaborasi yang dibangun antara pemerintah dengan lembaga swadaya masyarakat misalnya, merupakan salah satu wujud kerjasama atas kepedulian pemerintah terhadap segala bentuk kegiatan masyarakat untuk menunjang perekonomian masyarakat menuju masyarakat yang mandiri dan kreatif.

Kelompok Budidaya Ikan Mina Bayu Lestari misalnya, kelompok ini adalah salah satu dari 19 kelompok budidaya yang ada di Kabupaten Kulon Progo yang mendapatkan bantuan dana APBD DIY dari Dinas Kelautan dan Peikanan Kabupaten Kulon Progo. pada sejarah awalnya kelompok ini berdiri karena adanya kepedulian warga masyarakat di sekitar Desa Hargomulyo yang prihatin akan kehidupan masyarakat desa yang memiliki ketergantungan terhadap sektor pertanian, akan tetapi sektor pertanian yang ada disana tidak didukung dengan kualitas saluran irigasi yang baik, sehingga sering kali pada saat musim kemarau maka disana akan sangat kekeringan dan bahkan minim air, sehingga pada musinm kemarau banyak sekali lahan-lahan kosong yang tidak dapat dimanfaatkan sebagai lahan pertanian karena keterbatasan air. Selain itu hal yang menarik dari kelompok budidaya ini adalah prestasinya yang gemilang, karena sudah pernah menjuarai lomba kelopok budidaya ikan pada tingkat Kabupaten, Provinsi dan bahkan menjuarai pada tingkat juara 1 Nasional pada tahun 2014-2015 yang di selenggarakan oleh Kementrian Kelautan dan Perikanan RI.

Keberhasilan yang dilakukan oleh Kelompok Budidaya Ikan Gurame Mina Bayu Lestari ini juga tidak terlepas dari dukungan dan keterlibatan pemerintah sebagai aktor kolaborasi untuk memberdayakan masyarakatnya dengan upaya terjun langsung meninjau kegiatan masyarakat yang dilakukan. Meskipun telah terwujud kerjasama yang dilakukan oleh Dinas Kelautan dan Perikanan Kabupaten Kulonprogo dan Pemerintah Desa Hargomulyo dalam upaya mewujudkan kemandirian masyarakat. Akan tetapi wujud kerjasama atau kolaborasi ini masih ada saja masalah mendasar yang masih sering terjadi antara lain seperti pola koordinasi yang masih belum berjalan secara baik dan wujud apresiasi yang diberikan kepada kelompok-kelompok UKM sering kali tidak tepat sasaran. Kerjasama antara UKM dengan pemerintah sangatlah penting untuk dilakukan karena hal ini akan menunjang terwujudnya pembangunan nasional.

Sehingga dari hasil latar belakang diatas peneliti tertarik untuk melihat dan memperdalam bagaimanakah peran antara masing-mmasing Stakeholder dalam pelaksanaan pemberdayaan masyarakat dalam perspektif Collaborative Governence? serta peneliti ingin melihat dan menganalisis 
terkait bagaimana bentuk Collaborative Governance yang terjadi antara masing-masing aktor kolaborasi dalam pelaksanaan kolaborasi?

\section{TINJUAN PUSTAKA}

Muchamad Zainuri (2016), dalam penelitianya "Tatakelola Pariwisata-Bencana dalam Perspektif Collaborative Governance (studi pariwisata bencana Vulkano tour merapi di kabupaten Sleman)" dengan metode penelitian Kualitatif (Wawancara, Diskusi Kelompok dan Dokumentasi) yang kemudian menghasilkan temuan bahwa Collaborative governance dalam pengelolaan pariwisatabencana vulkano tour merapi dalam hal ini terwujud dengan peran antara pemerintah, swasta dan masyarakat dalam mewujudkan pariwisata-bencara dengan konsep pembangunan daerah telah terlaksana secara baik. Dalam penelitian ini juga di jelaskan tentang bentuk collaborative gobvernance dalam konteks pariwisata-bencana di kabupaten Sleman telah mengalami transformasi dari hubungan yang bersifat informal menjadi hubungan formal, dari komando menuju kolaborasi dan dari hubungan share vision menuju hubungan kemitraan antara pemerintah dengan masyarakat disekitar lokasi bencana. (Zainuri, 2016)

Menurut Denok Kurniasih, Paulus Israwan Setyoko \& Mohammad Imron (2017), dalam penelitian "Collaborative Governance Dalam Penguatan Kelembagaan Program Sanitasi Lingkungan Berbasis Masyarakat (SLBM) di Kabupaten Banyumas”. Dengan jenis Penelitian Kualitatif dengan mengunakan teknik Wawancara dan Diskusi Kelompok dalam penelitianya memperoleh hasil bahwa Collaborative governance antara pemerintah dan masyarakat dalam penelitian ini terletak pada pelaksanaan program sanitasi lingkungan berbasis masyarakat yang masih bersifat top-down sehingga masih banyak masyarakat yang belum mengerti daan belum memahami maksud kegiatan program yang dilakukan. Selain itu peran pemerintah dan KSM kabupaten Banyumas juga dirasa belum ada inisiatif untuk terjun langsung kelapangan dan melakukan sosisalisasi terkait program inovasi tersebut kepada masyarakat sehingga masih banyak masyarakat yang belum mengerti dan paham akan kegiatan program SLBM di kabupaten Banyumas. (Kurniasih, Setyoko, \& imron, 2017)

Nur Hayati \& Suparjan (2017), dalam penelitian "Kemitraan Sebagai Strategi Pemberdayaan Masyarakat Dalam Program CSR Batik Cap Pewarna Alami PT. Semen Gresik Pabrik Tuban”. Dengan metode penelitian Kualitatif (Wawancara, Observasi dan Dokumentasi), Dalam penelitian ini sasaran Collaborative Governance yang akan terjalin adalah kerjasama antara pihak PT. Semen Gresik dengan masyarakat daerah tuban lewat lembaga swadaya masyarakat yaitu KPR (Koalisi Perempuan Ronggolawe) untuk mencari 20 orang pekerja yang akan dilakukan dengan pembinaan dan pelatihan membatik. Sehingga pada penelitian ini pihak yang diuntungkan adalah masyarakat karena masyarakat selain dapat menambah ilmu dan wawasan serta keterampilan dalam proses pembuatan batik cap pewarna alami masyarakat juga diharapkan kedepannya dapat meciptakan peluang pekerjaan dan meningkatkan pembangunan ekonomi masyarakat menjadi lebih baik di daerah Tuban. . (Hayati \& Suparjan, 2017)

Indri Probuwati (2018), dalam penelitian "Collaborative Governance Dalam Program Kampung UKM Digital Kabupaten Bantul Tahun 2016 (studi kasus sentra kerajinan batik kayu krebet, kecamatan Pajangan, kabupaten Bantul)". Dengan mengunakan metode penelitian Kualitatif (Wawancara,dan Dokumentasi) dengan hasil penelitian bahwa Collaborative governance yang dilakukan pada program UKM Digital di kabupaten Bantul. Bentuk kolaborasi yang dilakukan pada program inovasi baru tersebut di pengaruhi oleh starting condition, facilitative 
leadership, share understanding dan collaborative process sehingga dalam proses pelaksanaanya sudah berjalan baik. Temuan dilapangan juga menunjukan bawa output dari hasil program UKM Digital di kabupaten Bantul telah merubahan kondisi masyarakat terutama dilihat dari segi ekonomi telah mengalami peningkatan karena adanya pelaksanan program UKM digital dan pelatihan-pelatihan yang dilakukan kepada masyarakat untuk peningkatan kerajinan batik kayu krebet. (Probowati, 2018)

Desni Azlin (2018), dalam penelitianya "Kolaborasi Pemerintah Desa dan Lembaga Adat Terhadap Pelestarian Kearifan Lokal di Desa Bandur Picak Kecamatan Koto Kampar Hulu Kabupaten Kampar Tahun 2014-2016”. Dengan metode penelitian Kualitatif (Wawancara dan Diskusi Kelompok), menghasilkan penelitian bahwa Bentuk collaborative governance yang terjadi pada penelitian ini adalah tentang tidak terjalinnya hubungan sinergisitas atas pemerintah Desa Bandur Picak dengan lembaga adat yang ada di desa tersebut, sehingga sering sekali terjadi miass komunikasi dan kesalah pahaman dalam penetapan kebijakan maupun kepercayaan antara pemerintah desa dengan lembaga adat dalam upaya melestarikan kearifan lokal desa Bandura Picak, Kecamatan Koto Kampar, Kabupaten Kampar Provinsi Riau. (Azlin, 2018)

\section{METODE PENELITIAN}

Jenis penelitian yang digunakan dalam penelitian ini adalah jenis penelitian deskriptif kualitatif, yakni untuk menjelaskan terkait bagaimana proses Collaborative Governance yang terjadi antara Kelompok Budidaya Ikan Mina Bayu Lestari dengan Stakeholder lain yang terlibat dalam proses kolaborasi. Metode penelitian Kualitatif juga sering diartikan sebagai metode penelitian naturalistik karena penelitiannya dilakukan pada kondisi yang alamiah (natural setting); disebut juga sebagai metode etnographi, karena pada awalnya metode ini lebih banyak digunakan untuk penelitian pada bidang antropologi budaya; disebut sebagai metode kualitatif, karena data yang terkumpul dan analisisnya lebih bersifat kualitatif. (Sugiyono, 2014).

Penelitian ini merupakan salah satu jenis penelitian lapangan yang dimana peneliti terjun langsung ke lokasi penelitian untuk mencari data-data yang diperlukan agar dapat dianalisis dalam penelitian ini. Data primer yang digunakan dalam penelitian ini adalah Wawancara, Observasi dan Dokumentasi yang berkaitan dengan proses pelaksanaan Collaborative Governance antara kelompok Budidaya Ikan Mina Bayu Lestari, Pemerintah Desa dan Dinas Kelautan dan Perikanan Kabupaten Kulon Progo guna meneliti dan mendapatkan fakta-fakta yang terperinci dan mendalam.

\section{LANDASAN TEORI}

\section{Collaborative Governance}

Menurut Dwiyanto dalam penelitian yang dilakukan oleh sulaksono, mengatakan bahwa Collaborative Governance praktek manajemen yang menghargai keragaman nilai, tradisi dan budaya organisasi, kerja dalam struktur yang relative longgar dan berbasis pada jaringan, dan dikendalikan oleh nilai-nilai dan tujuan bersama serta memiliki kapasitas mengelola konflik. (sulaksono, Suswanta, \& Efendi, 2017)

Collaborative Governance adalah cara pengelolaan pemerintah yang melibatkan secara langsung stakeholder diluar negara, berorientasi pada consensus, dan musyawarah dalam proses pengambilan keputusan kolektif, yang memiliki tujuan untuk membuat atau melaksanakan 
kebijakan dan program publik. Komponen proses kolaborasi terdiri dari dialog, membangun kepercayaan, komitmen untuk proses, pemahaman bersama antar lembaga terkait. (Ansell \& Gash, 2007) .

Bagan 1 Model Collaborative Governance menurut Ansel dan Gash (2007)

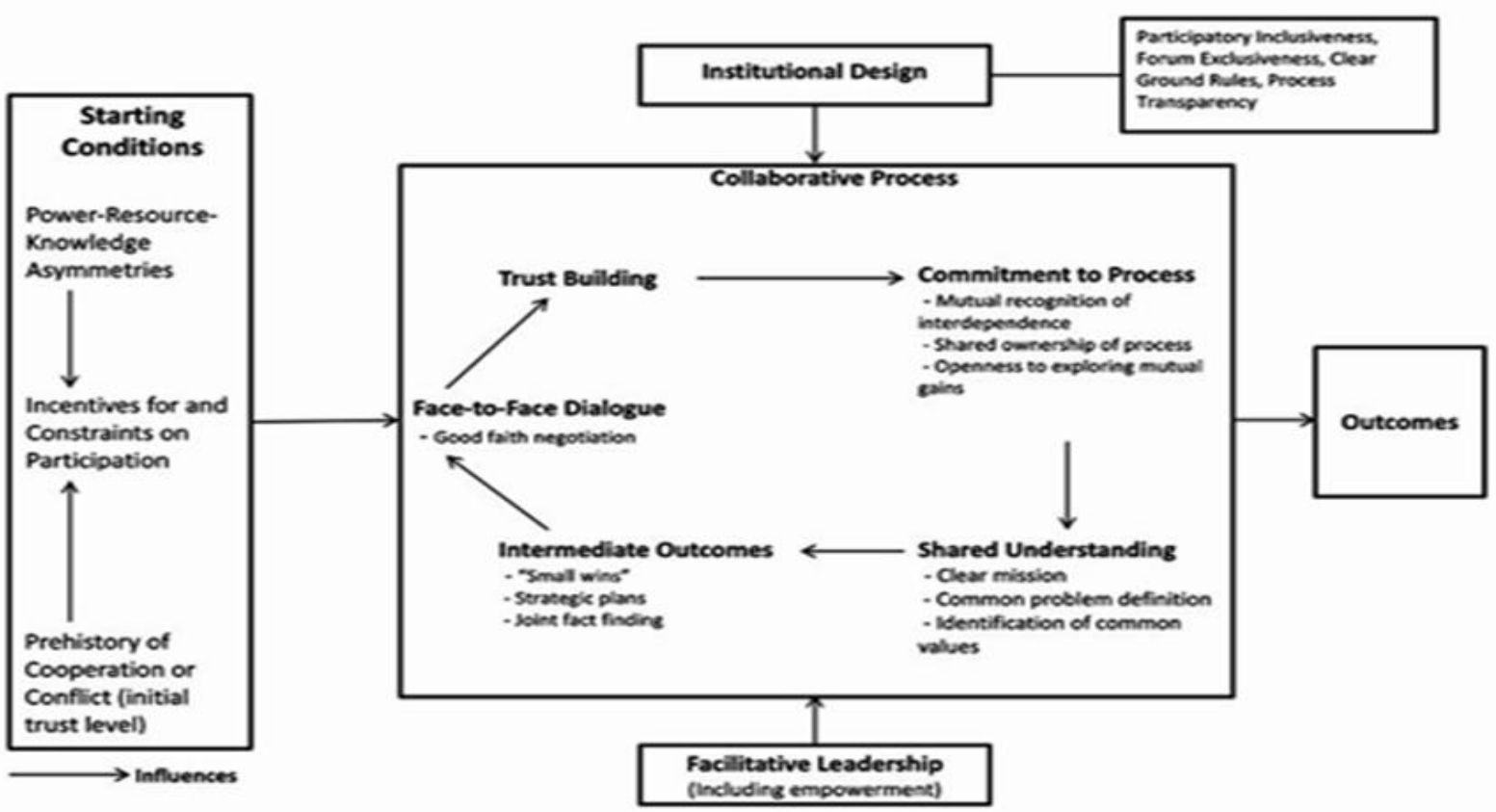

Sumber: diambil dari penelitiannya (Probowati, 2018)

Ansel dan Gash juga menjelaskan bahwa dalam proses kolaborasi menurutnya harus memiliki dan memenuhi komponen-komponen seperti: 1) Starting Condition (Kondisi Awal); 2) Fasilitative Leadership (Kepemimpinan fasilitatif); 3) Instituional Design (Disain Institusional); 4) Collaborative Proces (Proses Kolaborasi). Didalam tahap kolaborasi ini terdapat beberapa fase yang harus dilakukan dalam proses pelaksanaan kolaborasi diantaranya: a) Dialog tatap muka; b) Membangun kepercayaan; c) Komitmen terhadap proses; d) Saling memahami dan e) Hasil sementara proses kolaborasi (Hermawan, 2016).

\section{Stakeholder}

Menurut Freedman dalam Saharudin (2013) menjelaskan bahwa stakeholder merupakan kelompok atau individu yang dapat mempengaruhi dan atau dipengaruhi oleh pencapaian tujuan dari sebuah program. Selain itu, Budimanta dkk dalam Saharudin (2013) juga menjelaskan bahwa stakeholder diartikan sebagai mereka yang memiliki kepentingan dan keputusan tersendiri, baik sebagai individu maupun sebagai perwakilan yang mewakili sebuah kelompok kepentingan jika dalam sebuah kelompok tersebut memiliki kekuasaan, kepentingan atau legitimasi terhadap program. (Saharuddin \& Siska , 2016)

Munawaroh juga menjelaskan bahwa konsep stakeholder dibedakan menjadi 2 jenis, yaitu internal stakeholder yang berupa sekelompok atau individu yang terlibat didalam sebuah lingkungan organisasi yang bertanggung jawab penuh akan kegiatan yang dilakukan. dan yang kedua adalah 
eksternal stakeholder yaitu sekelompok individu yang bukan bagian suatu organisasi akan tetapi memiliki pengaruh dalam sebuah organisasi. (Munawaroh, 2016)

Sedangkan menurut Reed dalam penelitian yang dilakukan oleh Rosdiana (2012) mengartikan dan menganalisis pemangku kepentingan itu dapat dilakukan dengan 3 hal sebagai berikut:

1. Mengidentifikasi kepentingan dan pemangku kepentingannya;

2. Mengelompokkan dan mengatagorikan kelompok kepentingan;

3. meneliti hubungan antar kelompok kepentingan. (Roslinda, 2012)

\section{HASIL PEMBAHASAN}

Pelaksanaan Collaborative governance dalam pelaksanaan Pembudidayaan ikan di desa Hargomulyo antara pemerintah dengan kelompok budidaya ikan Mina Bayu Lestari dapat di ukur dengan perspektif collaborative governance menurut teorinya Ansel dan Gash (2007). Hal ini dilakukan karena dalam kegiatan kolaborasi yang dilakukan antara kelompok budidaya ikan Mina Bayu Lestari dengan pemerintah Desa Hargomulyo maupun dengan Dinas Kelautan dan Perikanan Kabupaten Kulon Progo dapat diukur dengan beberapa indikator antara lain :

\section{Mengetahui dan Mengidentifikasi Kepentingan dan Pemangku Kepentingan.}

Dalam pelaksanan sebuah kolaborasi, tentu saja tidak akan jauh kaitanya dengan peran aktor-aktor kepentingan dalam proses kolaborasi. Aktor-aktor yang berperan dalam kegiatan kolaborasi baik yang dilakukan antara beberapa pihak kepentingan maupun banyak pihak kepentingan sering kali kita dengar dengan nama Stakeholder. Stakeholder sendiri ada karena adanya keinginan atau kepentingan antara beberapa aktor kolaborasi yang memiliki tujuan dan keinginan yang sama atas dasar keuntungan yang didapat dalam proses kegiatan kolaborasi yang dilakukan. Dalam kegiatan proses collaborative governance yang dilakukan antar beberapa aktor kepentingan biasanya melibatkan pemerintah sebagai fasilitator, swasta sebagai aktor pendukung dan masyarakat sebagai aktor pelaksana pembudidayaan ikan.

Pemerintah Kabupaten dalam hal ini Dinas Kelautan dan Perikanan Kabupaten Kulon Progo memiliki peran sentral yaitu sebagai pemberi fasilitator seperti yang di jelaskan dalam naskah perjanjian dana hibah yang menjelaskan bahwa pihak pertama dalam hal ini Dinas Kelautan dan Perikanan Kabupaten Kulon Progo berkewajiban untuk menyerahkan hibah sarana produksi gurame kepada penerima hibah yang dalam hal ini berupa pendanaan, bibit ikan gurame, pakan ikan gurame dan peralatan lain dalam menunjang pembudidayaan ikan gurame yang dilakukan oleh kelompok budidaya. Selain bertindak sebagai fasilitator dalam proses kolaborasi, Dinas juga menurut hak dan kewajiban dalam naskah hibah tersebut, berkewajiban untuk melakukan verifikasi dokumen kelengkapan pengajuan hibah dan pertanggungjawaban pemanfaatan hibah oleh kelompok budidaya serta melakukan pengawasan dan evaluasi penggunaan hibah dalam proses kolaborasi yang dilakukan. Selain itu, dalam pelaksanaan kolaborasi, Dinas Kelautan dan Perikanan juga melakukan koordinasi dengan Pemerintah Desa Hargomulyo selaku kepala pemerintahan pada tingkat desa untuk melakukan pembinaan dan juga memonitoring dalam pelaksanaan kegiatan pembudidayaan ikan gurame yang dilakukan oleh kelompok budidaya ikan Mina Bayu Lestari. 
Bagan 3.1

Siklus pola hubungan stakeholder dalam proses kolaborasi

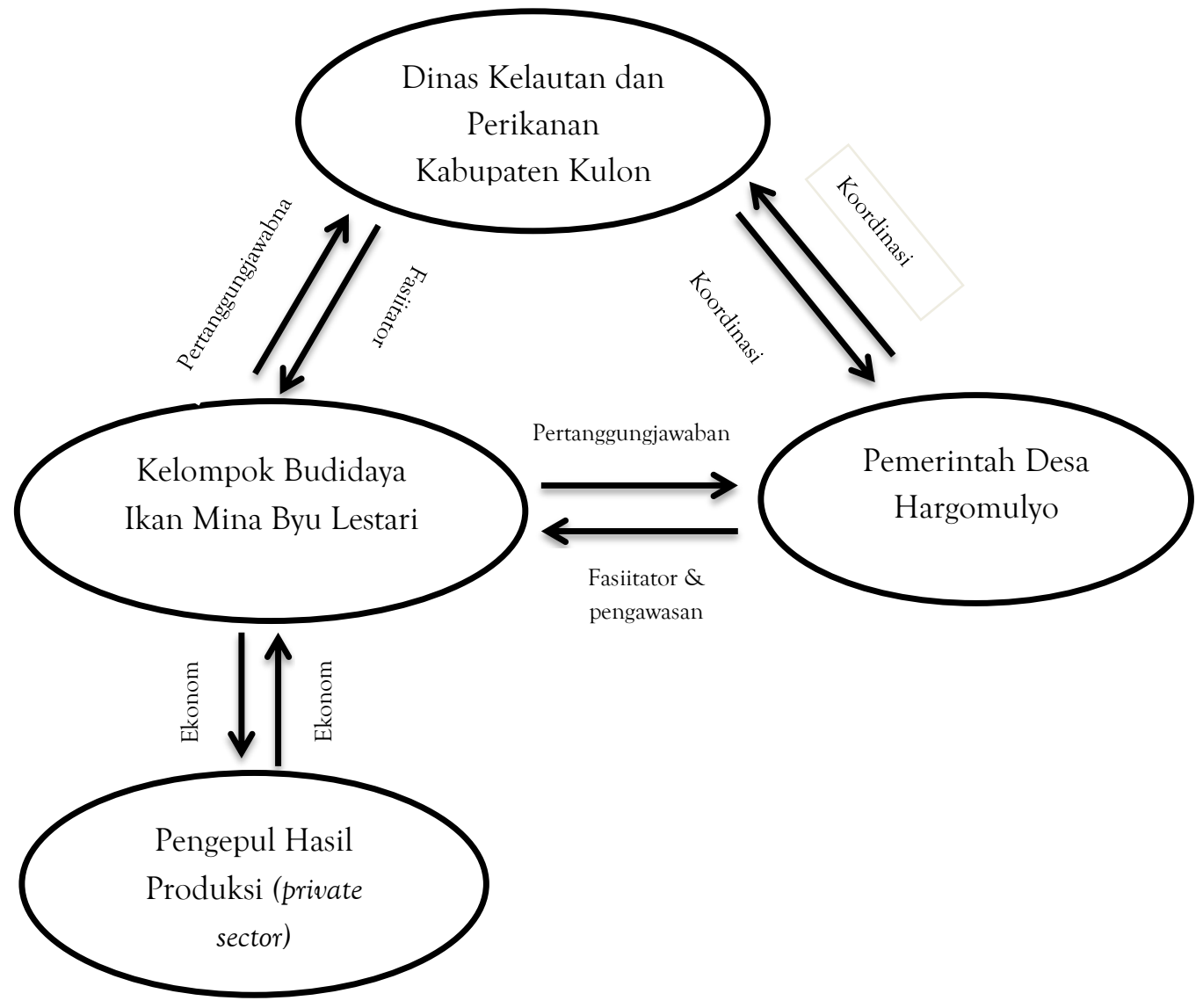

Sumber: Data primer Dinas Kelautan dan Perikanan Kab. Kulon Progo, 2018

Pemerintah Desa Hargomulyo dalam bagan tersebut berposisi sebagai kepanjang tanganan pemerintah kabupaten dalam hal ini Dinas Kelautan dan Perikanan, sehingga dalam pelaksanaan kollaborasi Pemerintah Desa Hargomulyo seperti pada bagan diatas selalu melakukan koordinasi dengan pemerintah kabupaten dan juga berkoordinasi juga dengan kelompok budidaya dalam proses kolaborasi yang berlangsung. Selain itu Pemerintah Desa juga bertindak sebagai fasilitator pendukung dalam upaya memenuhi segala bentuk kebutuhan yang diinginkan oleh kelompok dalam proses pembudidayaan ikan sesuai dengan kemampuan dan kompetensi yang dimiliki oleh pemerintah agar dapat mewujudkan proses kolaborasi dalam pembudidayaan ikan, sehingga dalam proses kolaborasi pemerintah desa dapat dikatakan kurang memiliki peran secara penuh, karena dalam proses kolaborasi tersebut lebih melibatkan antara Pemerintah Kabupaten dengan Kelompok Budidaya Ikan, akan tetapi peran pemerintah desa dalam proses kolaborasi tetap dibutuhkan sebab pemerintah desa dalam hal ini akan membantu melakukan pengawasan terkait pelaksanaan kolaborasi membantu peran dari pemerintah Kabupaten, dalam hal ini Dinas Kelautan dan Perikanan Kabupaten Kulon Progo. 
Kelompok Budidaya Ikan Mina Bayu Lestari selaku masyarakat yang menjalankan proses pembudidayaan tentu saja memiliki peran yang sangat dominan dan juga sentral dalam proses kolaborasi yang terjadi, kelompok budidaya ikan Mina Bayu Lestari seperti yang dijelaskan dalam bagan diatas selain memiliki hak dan tanggung jawab kepada Dinas Kelautan dan Perikanan Kabupaten Kulon Progo dalam proses pelaksanaan collaborative governance secara langsung, kelompok budidaya ikan Mina Bayu Lestari juga selalu melakukan koordinasi langsung dengan Pemerintah Desa Hargomulyo dalam pelaksanaan kolaborasi, sehingga pemerintah desa selaku kepala pemerintahan pada tingkat desa selalu dilibatkan dalam proses kegiatan kolaborasi dan bertanggung jawab pula dalam proses pelaksanaan kolaborasi yang terjadi. Sehingga hal ini selain memiliki tanggung jawab besar sebagai subyek pelaksana proses pembudidayaan ikan gurame, kelompok juga memiliki tanggungjawab sesuai dengan naskah perjanjian hibah yaitu untuk dapat memanfaatkan fasilitas hibah sarana budidaya yang diberikan sesuai dengan ketentuan yang berlaku dalam naskah perjanjian tersebut. Dalam naskah perjanjian tersebut dijelaskan pula bahwa pihak kedua dalam hal ini kelompok budidaya ikan Mina Bayu Lestari berkewajiban untuk menyampaikan laporan pertanggungjawaban kepada Dinas sesuai dengan ketentuan pada naskah perjanjian tersebut. Selain itu dalam proses collaborative governance yang terjadi, kelompok budidaya ikan Mina Bayu Lestari juga yang melakukan koordinasi secara langsung dengan pengepul (swasta) dalam proses penjualan hasil produksi ikan gurame tanpa harus ada perantara atau campur tangan antara Dinas maupun pemerintah Desa karena dalam proses penjualan hasil produksi ikan ini sepenuhnya dikembalikan kepada kelompok, sedangkan Dinas Kelautan dan Perikanan beserta Pemerintah Desa wajib mendapatkan hasil dari laporan pertanggungjawaban selambat-lambatnya satu bulan sebelum masa perjanjian hibah selesai atau sesuai dengan isi perjanjian hibah yang telah disepakati.

Pengepul hasil produksi ikan (private sector) dalam proses kolaborasi hanya berperan dan memiliki peran pada tahap akhir proses kolaborasi, yaitu pada saat penjualan hasil produksi yang dimana peran pengepul yang bertindak sebagai penerima sekaligus pembeli hasil produksi pembudidayaan ikan gurame secara langsung berhubungan dengan kelompok budidaya ikan saja, tanpa harus berkoordinasi dengan stakeholder lainnya, sehingga dalam pelaksanaan collaborative governance aktor swasta tidak memiliki peran yang sentral akan tetapi tetap memiliki peran yang sangat penting dalam proses kolaborasi terutama dalam tahap penjualan hasil produksi ikan gurame dari masyarakat dan kelompok budidaya.

\section{Peran Stakeholder dalam Proses Collaborative Governance}

Dalam proses collaborative governance Peran Dinas Kelautan dan Perikanan dalam proses kolaborasi dengan tujuan pemberdayaan masyarakat di desa hargomulyo dalam hal ini bertindak sebagai fasilitator dalam proses kolaborasi dengan menyediakan seluruh fasilitas dan kebutukan proses kolaborasi dari pembenihan, terpal atau alas kolam dan juga pakan ikan, kecuali pembuatan kolam yang dilakukan secara mandiri oleh kelompok budidaya. Hal ini sesuai degan yang dikatakan oleh Kabid Pembudidayaan Ikan, yang mengatakan bahwa:

"Dalam kegiatan kolaborasi ini, pemerintah bertindak sebagai fasilitator saja mas, nah untuk eksekusinya nanti di kembalikan lagi kepada masyarakat akan tetapi tetap dalam kontroling dan monitoring kami, sehingga kami juga bertujuan untuk memastikan kegiatan pembudidayan tetap berjalan sesuai dengan semestinya”. (Wawancara dengan pak Leo tanggal 12 November 2018). 
Kemudian untuk peran pemerintah Desa Hargomulyo dalam pembudidayaan ikan sejauh ini hampir sama dengan Dinas Kelautan dan Perikanan Kabupaten Kulon Progo yaitu sebagai fasilitator yang mendukung ketika kelompok budidaya ikan Mina Bayu Lestari membutuhkan bantuan dalam proses kolaborasi terutama dalam hal administrasi dan informasi terkait budidaya yang di informasikan lewat Pemerintah Desa. Sedangkan untuk peran kelompok budidaya dalam pembudidayaan ikan gurame, sudah jelas bahwa peran masyarakat dalam hal ini menjadi tolak ukur sebuah keberhasilan proses kolaborasi, wujud keberhasilan peran masyarakat dalam memanfaatkan peluang dan memanfaatkan fasilitas yang diberikan oleh pemerintah secara langsung, dapat dilihat dan dirasakan dengan keberhasilan masyarakat dan ketekunan masyarakat kelompok budidaya ikan Mina Bayu Lestari yang berhasil menorehkan prestasi mereka pada tingkat nasional, dengan berhasil membawa pulang teropi juara 1 pada tingkat nasional. Selain itu wujud peran masyarakat dalam proses collaborative governance dapat dilihat juga dengan wujud aktifnya kelompok budidaya dan keaktifan masing-masing kelompok budidaya yang secara berkesinambungan selalu melakukan koordinasi dan kolaborasi dengan pemerintah dalam segala bentuk kegiatan yang berkaitan dengan proses kolaborasi baik koordinasi dengan Pemerintah Desa, maupun dengan Dinas Kelautan dan Perikanan kabupaten Kulon Progo dalam pelaksanaan kolaborasi.

\section{Hubungan Yang Terjadi Antar Stakeholder Dalam Kolaborasi}

Dalam kegiatan collaborative governance yang dilakukan Dinas Kelautan dan Perikanan Kabupaten Kulon Progo dengan melaksanaan pemberdayaan masyarakat di Desa Hargomulyo lewat pembudidayaan ikan gurame dengan melibatkan kelompok budidaya ikan Mina Bayu Lestari dalam pelaksanaanya dapat dikatakan berhasil dan baik. Hal ini dapat dilihat dari kepedulian dan hubungan baik antara kelompok budidaya dengan pemerintah sebagai fasilitator dalam kegiatan collaborative governance. Selain itu setiap awal tahun sejak tahun 2012 saat awal terjalinnya proses kolaborasi hingga saat ini pemerintah selalu memberi bantuan fasilitas-fasilitas yang dibutuhkan oleh kelompok budidaya ikan Mina Bayu Lestari dalam setiap pengembangan dan kegiatan yang berkaitan dengan pembudidayaan ikan gurame seperti bibit ikan, pakan ikan, terpal dan fasilitas lain yang digunakan sebagai penunjang kegiatan pembudidayaan yang dilakukan oleh kelompok ikan Mina Bayu Lestari.

Selain itu hubungan yang terjalin antara masing-masing stakeholder dalam proses kegiatan collaborative governance untuk sejauh ini sudah berjalan secara baik dan keberlanjutan, hal ini dapat dilihat dengan telah berjalannya peran masing-masing aktor dalam proses kolaborasi sesuai dengan tugas dan kewajibannya baik itu pemerintah kabupaten lewat kedinasan atau pemerintah desa yang selalu berkoordinasi dan mamantau perkembangan kelompok budidaya secara langsung serta kelompok masyarakat pembudidaya ikannya yang secara aktif selalu berkolaborasi dalam melakukan budidaya dan aktif dalam kegiatan forum-forum terkait pelaksanaan budidaya ikan gurame yang disedikan oleh pemerintah.

\section{Starting Condition (Kondisi Awal)}

Starting condition atau kondisi awal tentang bagaimana proses kolaborasi atau kerjasama antara pemerintah lewat Dinas Kelautan dan Perikanan Kabupaten Kulon Progo dengan Kelompok Budidaya Ikan Mina Bayu Lestari dalam membudidayaan ikan gurame pada awalnya berangkat dari kesadaran masyarakat yang ingin maju dan berkembang atas keprihatinan diri 
sendiri dan lingkungannya yang banyak dari masyarakat Desa Hargomulyo terkhusus pedukuhan Tonobakal yang masih menganggur dan tidak memiliki pekerjaan yang tetap sehingga terbentuklah sebuah kelompok budidaya yang kemudian pada tahun 2012 pemerintah kabupaten mengetahui keberadaan kelompok lalu pemerintah melakukan pendampingan dan penyuluhan tentang prosedur yang harus dilakukan kelompok untuk dapat mengakses fasilitas yang disediakan oleh pemerintah bagi kelompok budidaya dalam upaya pengembangan usaha budidaya ikan gurame, sehingga pada tahun yang sama pemerintah melakukan kolaborasi dengan kelompok dalam upaya pembudidayaan ikan gurame di Desa Hargomulyo lewat kelompok budidaya ikan Mina Bayu Lestari. Pada awal proses kolaborasi, pemerintah desa belum memiliki keterlibatan yang signifikan, keterlibatan desa dalam proses kolaborasi mulai terlihat dengan telah disahkannya Undang-Undang Desa No 6 Tahun 2014 yang menyatakan bahwa desa memiliki dana desa sendiri, kemudian pada tahun 2016 atau setelah kelompok budidaya memperoleh juara 1 nasional, barulah desa mulai memiliki keterlibatan dalam proses kolaborasi akan tetapi tetap hanya memberikan bantuan secara stimulan saja kepada kelompok sesuai kebutuhan kelompok budidaya sedangkan untuk aktor swasta seperti Toke dan Pengepul keterlibatannya dalam proses kolaborasi adalah pada tahap penjualan hasil produksi pembudidayaan ikan gurame saja, karena dalam kegiatan kolaborasi ini keterlibatan aktor swasta tidak terlalu terlihat dan mendominansi.

\section{Facilitative Leadership (Kepemimpinan Fasilitatif)}

Dalam proses Collaborative Governance antara Kelompok Budidaya Ikan Mina Bayu Lestari dengan Pemerintah Desa dan Dinas Kelautan dan perikanan Kabupaten Kulon Progo pada tahap Facilitatif Leadership kegiatan pembudidayaan ikan gurame untuk proses kepemimpinannya tetap dibawah naungan Kabid Pembudidayaan Ikan Dinas Kelautan dan Perikanan Kabupaten Kulon Progo bapak Leo, selaku yang menaungi seluruh kelompok budidaya di Kabupaten Kulon Progo. Meskipun demikian dalam konteks kerjasama yang terjadi antara kelompok budidaya ikan Mina Bayu Lestari dengan pemerintah Kabupaten dan Pemerintah Desa untuk kepemimpinan dalam proses kolaborasi tetap mimiliki masing-masing koordinator yang diantaranya untuk Dinas Kelautan dan Perikanan yang di koordinatori oleh Kabid Pembudidayaan Ikan bapak Leo Handika, untuk pemerintah desa di koordinatori oleh Kepala Desa Hargomulyo bapak Burhani Arwin dan untuk masyarakatnya (society) di koordinatori oleh bapak Yantoro selaku ketua kelompok. Sehingga masing-masing koordinator memiliki tujuan untuk dapat berkoordinasi dalam setiap kegiatan pembudidayaan serta memastikan bahwa proses pembudidayaan ikan dapat berjalan sesuai dengan apa yang di inginkan oleh masing-masing stakeholder.

\section{Institusional Design (Disain Istitusional)}

Institusional Design dalam kegiatan Pembudidaya Ikan Gurame yang dilakukan antara Dinas Kelautan dan Perikanan Kabupaten Kulon Progo dengan Klompok Budidaya Ikan Mina Bayu Lestari di Desa Hargomulyo terdapat dalam sebuah perjanjian kerjasama berbentuk Naskah Perjanjian Hibah yang didalamnya menjelaskan Tugas, Hak dan kewajiban stakeholder yang terlibat dalam proses kolaborasi.

Dalam Naskah Perjanjian Hibah tersebut pada pasal Pasal 1 membahas tentang Tujuan Pelaksanaan Hibah, kemudian pada Pasal 2 berisi t Lingkup Pekerjaan yang diberikan kepada kelompok yang berupa (terpal, pakan dan benih ikan), pada Pasal 3 berisi tentang Nominal atau Jumlah Hibah yang diberikan Dinas Kelautan dan Perikanan Kabupaten Kulon Progo sesuai 
dengan kesepakatan dan kemampuan pemerintah dalam memenuhi nominal jumlah hibah yang di inginkan, pada Pasal 4 berisi tentang Hak dan Kewajiban dinas dalam memberikan fasilitas kepada kelompok yang berupa memiliki hak untuk menerima hasil laporan pertanggungjawaban dan berkewajiban untuk memberikan bantuan fasilitas sesuai perjanjian yang tertulis serta berkewajiban untuk mengatur, mengontrol dan memverifikasi dokumen yang dimiliki oleh kelompok dalam proses kolaborasi. Pada Pasal 5 juga diatur terkait Hak dan Kewajiban pihak kedua yaitu kelompok budidaya ikan Mina Bayu Lestari yang berhak menerima hibah yang diberikan oleh dinas dan kemudian kelompok berkewajiban untuk memberikan laporan pertanggungjawaban pengunaan dan pemanfaatan hibah sesuai dengan waktu yang ditentukan dalam naskah perjanjian hibah tersebut. Kemudian pada Pasal 6 dijelaskan tentang Waktu Pelaksanaan Hibah, pada Pasal 7 dibahas tentang Laporan dan Pertanggungjawaban, Pasal 8 membahas tentang Sanksi dan pasal ke 9 membahas tentang Ketentuan Penutup. Selain itu dalam proses kolaborasi dalam rangka mempermudah koordinasi antar aktor kolaborasi juga sudah ada forum-forum formal ataupun nonformal yang akan membahas tentang proses pembudidayaan ikan secara lebih mendalam antar masing-masing aktor.

\section{Collaborative Proces (Proses Kolaborasi)}

Dalam proses kolaborasi pelaksanaanya terdiri dari beberapa fase atau tahap agar proses kolaborasi dapat dijalankan secara maksimal. Dalam proses collaborative governance yang terjadi dalam program pembudidayaan ikan gurame di Desa Hargomulyo antara Kelompok Budidaya Ikan Mina Bayu Lestari, Pemerintah Desa dan Dinas Kelautan dan Perikanan Kabupaten Kulon Progo serta keterlibatan pengepul atau toke sebagai aktor swasta dapat dilihat melalui beberapa proses kolaborasi sebagai berikut:

\section{Face to face dialog (Dialog tatap muka)}

Dialog tatap muka (face to face dialog) dalam proses collaborative governance yang terjadi antara kelompok budidaya ikan Mina Bayu Lestari dengan Dinas Kelautan dan Perikanan Kabupaten Kulon Progo dan Pemerintah Desa Hargomulyo dalam memberdayakan masyarakatnya lewat kegiatan budidaya ikan gurame dilakukan dengan dengan 2 cara yaitu dengan cara formal dan nonformal. Dialog formal dilakukan dengan cara mengundang seluruh stakeholder yang terlibat dalam proses kolaborasi dengan rapat-rapat koordinasi yang bersifat resmi. Sedangkan dialog nonformal lebih bersifat kepada dialog tata tatap muka yang dilakukan secara tidak resmi ditempat-tempat yang lebih santai seperti warung kopi atau lokasi pembudidayaan ikan. Dengan dilakukannya dialog tatap muka yang dilakukan dengan intensitas tertentu baik secara formal ataupun nonformal maka secara sadar atau tidak sadar itu akan membangun rasa kepercayaan (trush building), komitmen terhadap proses (commitment to process) dan sikap saling memahami antar stakeholder (share understanding).

\section{Trust Building (Membangun Kepercayan)}

Cara membangun kepercayaan antar masing-masing stakeholder dalam proses kolaborasi dalam penelitian ini dapat tumbuh dengan adanya koordinasi sesama aktor kolaborasi dengan komunikasi yang baik. Komunikasi yang baik dalam proses collaborative governance.komunikasi yang terjalin dalam program pembudidayaan ikan gurame antara masing-masing stakeholder dalam proses kolaborasi ini dapat dikatakan sudah baik dilakukan. hal ini diperkuat dengan telah adanya trush 
building dalam collaborative governance yang terjalin antar aktor dengan cara yang sederhana yaitu dengan adanya aturan yang mengikat sebelumnya yang berupa Naskah Perjanjian Hibah yang didalamnya telah membahas terkait tugas, hak, kewajiban dan serta sanksi-sanksi yang mengikat masing-masing aktor dalam kolaborasi. Selain itu dalam upaya membangun kepercayaan masingmasing aktor kolaborasi dalam pelaksanaan collaborative governance sering dilakukannya dialog antar aktor kolaborasi dalam pelaksanaan pembudidayaan yang dilakukan secara formal dan nonformal sehingga komunikasi yang terjadi antar aktor tetap terjaga dan antar aktor dalam pelaksanaan kolaborasi sudah menumbuhkan sikap saling percaya dengan intensitas pertemuan dan aktifitas dialog yang dilakukan secara langsung maupun tidak langsung.

\section{Comitment to process (Komitmen terhadap proses)}

Commitment to process (komitmen terhadap proses) dalam collaborative governance dalam program pembudidayaan ikan antara Kelompok Budidaya Ikan Mina Bayu Lestari dengan Dinas Kelautan dan Perikanan Kabupaten Kulon Progo dan Pemerintah Desa Hargomulyo muncul karena adanya kepercayaan yang kuat antara masing-masing aktor kolaborasi itu sendiri. Selain itu komitmen juga dijalankan karena pada saat perjanjian awal sudah adanya kesepakatan yang diwujudkan dengan naskah perjanjian dan keinginan kuat dari masyarakat untuk peningkatan hasil produksi dan juga ekonomi masyarakat serta masing-masing stakeholder seperti Dinas Kelautan dan Perikanan Kabupaten Kulon Progo bersama pemerintah Desa Hargomulyo dalam upaya menjadikan Desa Hargomulyo sebagai desa penghasil produksi pembudidayaan ikan gurame terbesar di daerah Kulon Progo dan pengentasan masalah kemiskinan di wilayah tersebut dengan pelaksanaan kegiatan pembudidaya ikan. Sehingga dengan adanya tujuan bersama serta keinginan yang kuat masing-masing aktor kolaborasi tersebut untuk mewujudkan cita-cita bersama dalam hal peningkatan hasil produksi, peningkatan ekonomi masyarakat dan menjadikan Desa Hargomulyo sebagai desa penghasil produksi budidaya ikan gurame terbesar di Kabupaten Kulon Progo komitmen terhadap proses kolaborasi sudah terjalin dan terlaksana secara baik.

\section{Share understanding (Sikap saling memahami)}

Share understanding yang terjadi dalam pembudidayaan ikan gurame yang melibatkan Dinas Kelautan dan Perikanan Kabupaten Kulon Progo dengan Kelompok Budidaya Ikan Mina Bayu Lestari dan Pemerintah Desa Hargomulyo selain dengan secara rutinnya pertemuan baik secara formal atau secara nonformal. Saling itu, media komunikasi juga sering kali digunakan seperti via telvon atau chatting dalam proses komunikasi yang dilakukan. Pengunaan alat komunikasi via telvon atau chatting ini dapat digunakan oleh para aktor kolaborasi ketika ada masalah-masalah yang bersifat mendadak atau incidental yang mengharuskan aktor kolaborasi menggunakan alat komunikasi jarak jauh ini. Akan tetapi meskipun demikian pengguanaan alat komunikasi jarak jauh ini hanya bersifat sementara saja, karena jika nantinya terdapat masalah yang harus diselesaikan secara lebih lanjut, antar stakeholder juga akan menyegerakan terjadinya pertemuan untuk dibahas lebih lanjut serta dicarikan solusinya.

\section{Intermediate outcome (Hasil sementara)}

Proses collaborative governance yang terjadi antara Dinas Kelautan dan Perikanan Kabupaten Kulon Progo dengan Kelompok Budidaya Ikan Mina Bayu Lestari dan Pemerintah Desa Hargomulyo dalam menjalankan kegiatan pembudidayaan ikan gurame sudah berjalan secara baik 
dan mendapatkan hasil. Akan tetapi meskipun demikian, masih ada beberapa kekurangan dalam pelaksanaan yang menyebabkan proses pelaksanaan collaborative governance dirasa masih belum sempurna. Kekurangan tersebut dilihat dari peran pihak swasta atau private sector yang hanya melibatkan Toke atau Pengepul pada tahap penjualan hasil produksi saja, selain itu keterlibatan Toke atau Pengepul dalam kegiatan kolaborasi juga dapat dikatakan masih belum terlibat secara aktif dan keterlibat swasta dalam proses kolaborasi hanya pada tahap pemasaran dari hasil produksi budidaya saja, sedangkan keterlibatan aktor swasta secara utuh cenderung tidak terlalu dominan.

Bagan 2

Model Collaborative Governance Pembudidayaan Ikan Gurame desa Hargomulyo

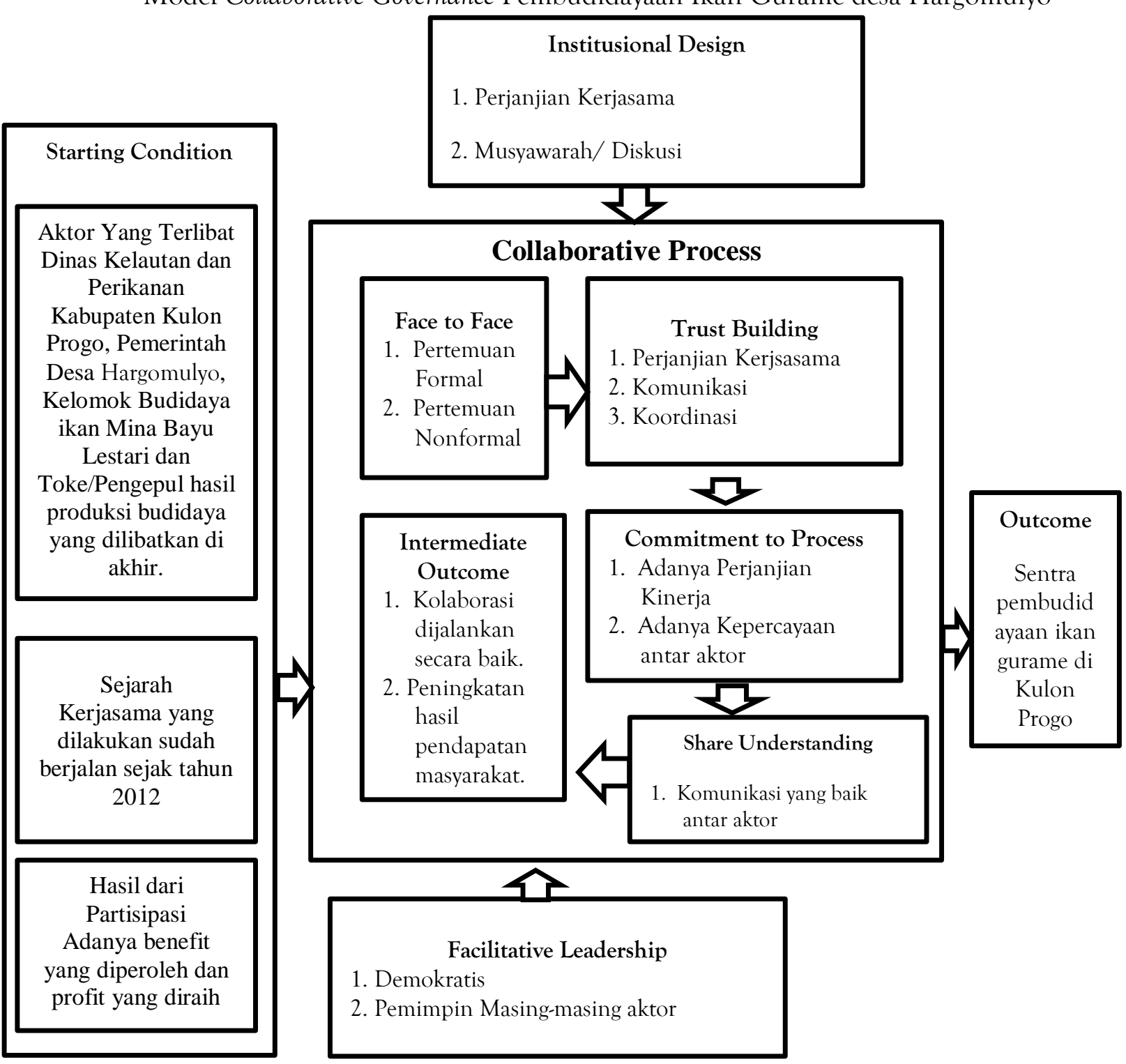

Sumber: Data diolah oleh peneliti

Sehingga dalam pelaksanaan collaborative governance menurut Ansel dan Gash (2007) kolaborasi yang dilakukan dapat dikatakan belum berjalan secara sempurna, padahal jika aktor 
swasta dalam proses kolaborasi dilibatkan dari awal proses kolaborasi dari mulai pakan sampai pemasaran maka penulis yakin proses kolaborasi akan berjalan jauh lebih maksimal dan lebih baik dari kolaborasi yang dilakukan saat ini. Dari penjelasan bagan diatas dapat disimpulkan bahwa dalam proses collaborative governance yang terjadi antara Dinas Kelautan dan Perikanan Kabupaten Kulon Progo dengan Kelompok Budidaya Ikan Mina Bayu Lestari dan Pemerintah Desa Hargomulyo dalam menjalankan kegiatan pembudidayaan ikan gurame sudah berjalan secara baik dan mendapatkan hasil. Akan tetapi meskipun demikian, masih ada beberapa kekurangan dalam pelaksanaan yang menyebabkan proses pelaksanaan collaborative governance dirasa masih belum sempurna. Kekurangan tersebut dilihat dari peran pihak swasta atau private sector yang hanya melibatkan Toke atau Pengepul pada tahap penjualan hasil produksi saja, selain itu keterlibatan Toke atau Pengepul dalam kegiatan kolaborasi juga dapat dikatakan masih belum terlibat secara aktif dan keterlibat swasta dalam proses kolaborasi hanya pada tahap pemasaran dari hasil produksi budidaya saja, sedangkan keterlibatan aktor swasta secara utuh cenderung tidak terlalu dominan. Sehingga dalam pelaksanaan collaborative governance menurut Ansel dan Gash (2007) kolaborasi yang dilakukan dapat dikatakan belum berjalan secara sempurna, padahal jika aktor swasta dalam proses kolaborasi dilibatkan dari awal proses kolaborasi dari mulai pakan sampai pemasaran maka penulis yakin proses kolaborasi akan berjalan jauh lebih maksimal dan lebih baik dari kolaborasi yang dilakukan saat ini.

\section{KESIMPULAN}

Berdasarkan hasil penelitian yang telah dipaparkan maka dapat dimpulkan bahwa pelaksanaan collaborative governance yang terjadi antara Dinas Kelautan dan Perikanan Kabupaten Kulon Progo, Kelompok Budidaya Ikan Mina Bayu Lestari dan Pemerintah Desa Hargomulyo dengan beberapa poit sebagai berikut : Pertama, keterlibatan Stakeholder dalam kegiatan kolaborasi pembudidayaan ikan gurame di Desa Hargomulyo meliputi 4 aktor stakeholder yaitu Dinas Kelautan dan Perikanan Kabupaten Kulon Progo, Pemerintah Desa Hargomulyo, Kelompok budidaya Ikan Mina Bayu Lestari dan Pengepul hasil produksi ikan gurame sebagai aktor swasta. Kedua, sedangkan dalam pelaksanaan collaborative governance yang terjadi seperti Starting condition, Facilitative leadership, Institusional design dan Collaborative Proces sampai pada tahap Hasil sementara yang diperoleh pada proses kolaborasi dalam pembudidayaan ikan gurame di Desa Hargomulyo sudah adanya peningkatan hasil produksi secara signifikan terutama peningkatan perekonomian anggota kelompok budidaya. Meskipun dalam pelaksanaan kolaborasi yang dilakukan secara keseluruhan dapat dikatakan cukup baik dan memperoleh hasil yang baik pula, akan tetapi dilihat dari perspektif Collaborative governance pelaksanaan kolaborasi ini masih belum sempurna karena belum adanya keterlibatan secara dominan 3 aktor utama kolaborasi yaitu Pemerintah, Masyarakat dan Swasta. Karena dalam penelitian yang dilakukan keterlibatan aktor swasta dalam hal ini Pengepul hasil produksi atau Toke yang biasanya membeli hasil produksi petani dalam proses kolaborasi hanya terlibat pada tahap penjualan hasil produksi saja, sedangkan secara keseluruhan keterlibatan pengepul dalam proses kolaborasi masih kurang dilakukan.

\section{SARAN}

Ada beberapa hal yang penulis ingin sarankan dalam penelitian ini, terutama pelaksanaan collaborative governance dalam proses pembudidayaan ikan gurame antara Dinas Kelautan dengan Kelompok Budidaya Ikan Mina Bayu Lestari dan Pemerintah Desa sebagai berikut: 
Pertama, meningkatkan kualitas dan kuantitas sumberdaya manusia terutama keterlibatan masyarakat Desa Hargomulyo dengan dilaksanakannya pelatihan-pelatihan terkait pelaksanaan pembudidayaan ikan gurame sebagai solusi pengentasan kemiskinan dan masalah pengangguran di Desa Hargomulyo. Kedua, meningkatkan proses kolaborasi dengan melibatkan aktor-aktor penting lain dalam proses kolaborasi seperti halnya Media dan Akademik. Ketiga, peningkatan peran dan keterlibatan aktor swasta dalam proses kolaborasi, sehingga nantinya selain diharapkan akan mendukung pelaksanaan collaborative governance lebih maksimal dilakukan, keterlibatan aktor swasta dalam proses kolaborasi juga dihapkan mampu menciptakan inovasi dibidang pemasaran bukan hanya pemasaran hasil budidaya ikan gurame mentah, tapi lebih ke inovasi pemasaran produk olahan ikan gurame sehingga dilihat dari segi ekonomis akan lebih menguntungkan dan menghasilkan.

\section{DAFTAR PUSTAKA}

Ansell, C., \& Gash, A. (2007). Collaborative Governance in Theory and Practice. Journal of Public Administration Reaserch and Theory, Published by Oxfod University Press, 542.

Anwas, O. M. (2014). Pemberdayaan Masyarakat di Era Global . Bandung: ALVABETA .

Azlin, D. (2018). Kolaborasi Pemerintah Desa dan Lembaga Adat Terhadap Pelestarian Kearifan Lokal di Desa Bandur Pecak Kecamatan Koto Kampar Hulu Kabupaten Kampar Tahun 2014-2016. Jurnal Fisip, Vol.5 No.1, Universitas Riau, 6-13.

Haryono. (2012). Jejaring Untuk Membangun Kolaborasi Sektor Publik. Jurnal Jejaring Administrasi Publik. Th IV. No 1., 48.

Hayati, N., \& Suparjan. (2017). Kemitraan Sebagai Strategi Pemberdayaan Masyarakat Dalam Program CSR Batik Cap Pewarna Alami di PT. Semen Gresik Pabrik Tuban. jurnal sosiologi USK, Vol.11, No.1, Universitas Gadjah Mada, 4-7.

Hermawan, B. (2016). Collaborative Governance Dalam Program Pengembangan Nilai Budaya Daerah Melalui Banywangi Ethno Carnival. 41.

Kurniasih, D., Setyoko, P., \& imron, M. (2017). Collaborative Governance Dalam Penguatan Kelembagaan Program Sanitasi Lingkungan Berbasis Masyarakat (SLBM) di Kabupaten Banyumas. jurnal sosiohumaniora, Vol.19, No.1, Universitas Jendral Soedirman, 3-5.

Mardikanto, T., \& Soebiato, P. (2017). Pemberdayaan Masyarakat dalam Perspektif Kebijakan Publik. Bandung: ALVABETA.

Munawaroh, K. (2016). Koordinasi Multistakeholder dalam Proses Rekruitmen Buruh Migran Asal Kabupaten Lampung Timur (Studi tentang Koordinasi Multistakeholder di kecamatan Way Jepara, Kabupaten Lampung Timur). Skripsi. Bandar Lampung: Universitas Lampung , $32-$ 33.

Probowati, I. (2018). COLLABORATIVE GOVERNANCE PROGRAM KAMPUNG UKM DIGITAL KABUPATEN BANTUL TAHUN 2016 (studi kasus kerajinan batik kayu krebet, kecamatan pajangan, kabupaten bantul). skripsi, Ilmu Pemerintahan UMY, 26-123.

Roslinda, E. (2012). Analisis Pemangku Kepentingan dalam Pengelolaan Taman Nasional Danau Sentarum Kabupaten Kapuas Hulu, Kalimantan Barat. JMHT, Vol XVIII, 78-85.

Saharuddin, \& Siska , O. (2016). Hubungan Peran Stakeholder dengan Partisipasi Masyarakat dalam Program Agropolitan Desa Karacak Kecamatan Leuwiliang Kabupaten Bogor. Jurnal Sosial Politik. Vol 1, No 3, 233. 
sedarmayanti. (2012). GOOD GOVERNANCE "Pemerintahan Yang Baik". Bandung: CV. Madar Maju.

Sugiyono. (2014). Metode Penelitian Kuantitatif, Kualitatif dan REDD. Bandung: Alfabeta. sulaksono, T., Suswanta, \& Efendi, D. (2017). Pengelolaan Wilayah Perbatasan Berbasis Stakeholders Collaborative Governance Studi di Kabupaten Nunukan, Kalimantan Utara. Penelitian Produk Terapan, Ilmu Pemerintahan. Universitas Muhammadiyah Yogyakarta, 16.

Zainuri, M. (2016). Tata Kelola Pariwisata Bencana Dalam Perspektif Collaborative Governance Studi Pariwisata-Bencana Volcano Tour Merapi di Kabupaten Sleman. Penelitian, Ilmu Pemerintahan, Universitas Muhammadiyah Yogyakarta, 11-15. 